\title{
Cushing disease in children and adolescents - assessment of the clinical course, diagnostic process, and effects of the treatment - experience from a single paediatric centre
}

\author{
Choroba Cushinga u dzieci i młodzieży - ocena przebiegu klinicznego, procesu diagnostycznego \\ i efektów terapeutycznych - doświadczenia pojedynczego ośrodka pediatrycznego
}
1,2Anna Wędrychowicz* , 1,2 Barbara Hull* , ${ }^{2}$ Katarzyna Tyrawa, ${ }^{1,2}$ Anna Kalicka-Kasperczyk, ${ }^{3}$ Grzegorz Zieliński, ${ }^{1,2}$ Jerzy Starzyk

\author{
${ }^{1}$ Institute of Paediatrics, Department of Children and Youth Endocrinology, Jagiellonian University Medical \\ College, Krakow, Poland \\ ${ }^{2}$ Division of Children and Youth Endocrinology, University Children's Hospital, Krakow, Poland \\ ${ }^{3}$ Department of Neurosurgery, Military Institute of Medicine, Poland
}

*These authors contributed equally to the manuscript.

\begin{abstract}
Introduction: Adrenocorticotropic hormone-dependent Cushing syndrome, known as Cushing disease (CD), is a rare disease in paediatric patients, the signs and symptoms of which differ from those seen in adult patients.

Aim of the study: The objective of the study was to present the diagnostics and treatment results of CD in children and adolescents. Material and methods: We included four consequent patients in the study, 7-15 years old, with CD confirmed by laboratory tests and finally by histology examinations after surgery. The data were retrospectively retrieved from the medical records of all the patients from the years 2012-2018.

Results: The median time from the onset of clinical symptoms to CD diagnosis was 1.5 years. All patients presented with rapid weight gain accompanying growth retardation, and behavioural, puberty, or menstruation disorders. The diagnostic process was carried out in accordance with the current standard. Diagnostic difficulties regarded the cyclic CD. All patients underwent transsphenoidal complete resection of the pituitary adenoma, and they all required transient glucocorticoid substitution for a period that correlated with the time from onset of symptoms to diagnosis. All subjects achieved normalisation of hormonal results and resolution of clinical symptoms, but all are still obese. Currently the patients are in remission, but there is a suspicion of the regrowth of the tumour mass in the eldest patient.

Conclusions: In each case of the coexistence of growth velocity inhibition (not necessarily short stature) with the weight gain (not necessarily obesity) and the appearance of hyperandrogenism and depressive-anxiety disorders, biochemical diagnostics of CS should be performed. Obesity could be a chronic complication of CD in childhood, even after effective neurosurgery treatment.
\end{abstract}

Key words:

Cushing disease, CD, children, adolescents, hypercortisolaemia.

\section{Streszczenie}

Wprowadzenie: Zespół Cushinga zależny od kortykotropiny (adrenocorticotropic hormone - ACTH), zwany również chorobą Cushinga (Cushing's disease - CD), jest rzadkim schorzeniem u dzieci i młodzieży, którego objawy różnią się od obserwowanych u osób dorosłych.

Cel pracy: Ocena procesu diagnostycznego i wyników terapii CD u dzieci i młodzieży.

Materiał i metody: Do pracy włączono 4 kolejne pacjentki w wieku 7-15 lat z CD rozpoznaną na podstawie wyników badań hormonalnych i badania histopatologicznego usuniętego gruczolaka przysadki po przeprowadzeniu retrospektywnej analizy dokumentacji medycznej pacjentów leczonych w naszym ośrodku w latach 2012-2018.

Wyniki: Mediana czasu od początku objawów klinicznych do rozpoznania CD w prezentowanej grupie pacjentów wynosiła 1,5 roku. Wszystkie pacjentki miały objawy CD typowe dla wieku rozwojowego: gwałtowny przyrost masy ciała z zahamowaniem 
tempa wzrastania, zaburzenia zachowania, dojrzewania bądź miesiączkowania. Diagnostyka pacjentów była przeprowadzona zgodnie z obowiązującym standardem, najwięcej trudności diagnostycznych sprawiła postać cykliczna CD rozpoznana u jednej z pacjentek. Wszystkie pacjentki przebyły przezklinową całkowitą resekcję gruczolaka przysadki. Po zabiegu wszystkie wymagały przejściowej substytucji glikokortykoidów w czasie, który wyraźnie korelował z długością czasu od wystąpienia objawów do ustalenia rozpoznania. U wszystkich uzyskano normalizację wyników hormonalnych i ustąpienie objawów klinicznych po leczeniu neurochirurgicznym, jednakże wszystkie pacjentki nadal są otyłe. W badaniach MR przysadki u 3 pacjentek nie stwierdza się odrostu masy guza, u najstarszej jest jego podejrzenie.

Wnioski: W przypadku współwystępowania zahamowania procesu wzrastania (niekoniecznie niskorosłości) z przyrostem masy ciała (niekoniecznie otyłości), cech androgenizacji i zaburzeń zachowania konieczne jest przeprowadzenie diagnostyki w kierunku CD. Otyłość może być stałym powikłaniem CD rozpoznanej w dzieciństwie mimo jej skutecznego leczenia neurochirurgicznego.

\section{Słowa kluczowe:}

choroba Cushinga, dzieci, młodzież, hiperkortyzolemia.

\section{Introduction}

After the age of five years, adrenocorticotropic hormone (ACTH)-dependent Cushing syndrome (CS) is more common than $\mathrm{ACTH}$-independent CS. In most cases ACTH is produced by the pituitary microadenoma and causes hypercortisolaemia resulting in obesity with simultaneous growth velocity inhibition, behavioural changes, and hyperandrogenism (precocious puberty, hirsutism, lack or regression of puberty due to the suppression of gonadal axis by adrenal androgens) $[1,2]$. The overproduction of ACTH by the pituitary adenoma occurs in a semi-autonomous manner and retains some autoregulatory properties of the hypothalamic-pituitary-adrenal axis in the negative feedback cycle. There are no symptoms of excess aldosterone [3]. In each case of the coexistence of the above features CS should be suspected and detailed, proper biochemical diagnostics should be performed. After the diagnosis of CS, the main goal of the treatment is a rapid normalisation of serum cortisol levels to prevent the adverse effects of prolonged hypercortisolaemia. In children, this is particularly important to prevent disorders of their somatic development [4].

The aim of the study was to present the diagnostics and treatment results of CD in children and adolescents, underling the differences in the clinical outcome of CD between paediatric patients and adults.

\section{Material and methods}

\section{Patients}

Four consequent patients, 7-15 years-old, with CD confirmed by laboratory tests and finally by histology examinations of removed pituitary adenoma, treated in our department in the years 2012-2018, were included in the study. All patients underwent transsphenoidal complete resection of the pituitary adenoma, performed by the same experienced neurosurgeon. The data were retrospectively retrieved from medical records of all the patients. The parents of the patients (and the patients above 16 years old) gave their written, informed consent for the presentation of the medical data in the journal article.

\section{Biochemical diagnostics}

The diagnosis of CD was made based on standard hormonal criteria: increased urinary-free cortisol (UFC) in three 24-h urine collections, disturbances of cortisol circadian rhythm, increased or not suppressed plasma ACTH levels at 8.00 a.m. accompanying increased serum cortisol levels, and a failure to suppress serum cortisol levels to $<1.8 \mu \mathrm{g} / \mathrm{dl}$ during an overnight dexamethasone suppression test (ODST; $1 \mathrm{mg}$ of dexamethasone was given at 11.00 p.m.). The pituitary aetiology of CS was confirmed based on serum cortisol or UFC suppression $<50 \%$ with a high-dose dexamethasone suppression test (HDDST; 2 mg q.i.d. for 48 h) or a positive result of a corticotrophin-releasing hormone $(\mathrm{CRH})$ stimulation test $(1 \mu \mathrm{g} / \mathrm{kg}$, maximum $100 \mu \mathrm{g}$ IV) and positive pituitary MRI.

Plasma ACTH levels were measured using radioimmunochemistry (Brahms, Germany). Serum cortisol concentrations were determined by indirect chemiluminescence using an Advia Centaur (Siemens Healthcare Diagnostics, USA). Serum levels of DHEA-S (Diasource, Belgium), PRA (DiaSorin, Italy before 2014, currently Immunotech, Czech Republic), and aldosterone (ZenTech, Belgium before 2014, currently Cisbio, France) were measured using radioimmunochemistry. Cortisol in urine was measured using isotope dilution mass spectrometry (Orion Diagnostica, Finland before 2013, in the years 2013-2017 Diasource, Belgium, currently Immunotech, Czech Republic).

\section{Treatment and postoperative outcome}

All patients underwent MRI of the pituitary (GE Signa, 1.5 Tesla) before and after IV injection of gadolinium (Gd-DTPA). A macroadenoma was defined as a tumour with at least one diameter $>10 \mathrm{~mm}$, and a microadenoma as a pathological mass with maximum diameter $\leq 10 \mathrm{~mm}$.

Histopathological examinations were performed in accordance with the 2004 WHO classification. Tissue samples were routinely immune-stained for all pituitary hormones. Ki-67 (MIB1) labelling index (LI) was graded in two categories: a) $<3$ and b) $\geq 3$. Corticotroph adenomas were classified on the basis of commonly accepted ultrastructural features, such as densely granulated (DG-ACTH) or sparsely granulated (SG-ACTH). 
Blood samples for serum cortisol were collected from all patients at $6.00 \mathrm{a} . \mathrm{m}$. on the first, second, and third postoperative days. Hydrocortisone replacement therapy was started after biochemical confirmation of hypocortisolaemia or when clinical manifestations of adrenal insufficiency were observed. An early, postoperative remission was recognised, when the nadir serum cortisol level taken at 6.00 a.m. on the first, second, and third postoperative day was $<1.8 \mu \mathrm{g} / \mathrm{dl}$. Late biochemical remission was recognised on the basis of hormonal assessments 6 months after pituitary surgery.

Statistical analysis

Statistical analysis of the clinical data was made using Excel (Microsoft Office Professional Plus 2016, PL).

\section{Results}

Patients' clinical signs and symptoms

All patients presented with obesity and a decrease in growth velocity at various times before CD diagnosis. Moreover, significant changes of the patients' behaviour were observed, such as depression or aggressive and auto-aggressive behaviours, weakness, less tolerance of physical exercise, and ravenous hunger. Our patients presented with hyperandrogenism such as precocious or delayed puberty (an arrest of breast development, primary amenorrhoea), secondary amenorrhoea. The youngest patient had cyclic presentation of CD symptoms (Table I).

Physical examination of patients 1-3 revealed Cushingoid face (round, moon face with plethora), axial obesity, swarthy skin, red massive striae on the abdomen, hips, and limbs, and hirsutism and severe acne located on the face and chest. In patient 1 there was also bruising of the skin, thinned skin on the lower legs, widened veins, numerous red spots on the back (candidiasis), and erythematous cutaneous eruptions. Only patient 4 did not present with striae, but cushingoid face, axial obesity, hirsutism, acanthosis nigricans on the neck, and precocious adrenarche (pubarche II stage according Tanner scale) in the absence of development of the breast glands (steatomastia) was seen. Blood pressure was elevated in two patients $(130 / 100 \mathrm{~mm} \mathrm{Hg}, 145 / 80 \mathrm{~mm} \mathrm{Hg})$, and it was within the normal range in the other two.

The results of anthropometric measurements are presented on growth and body mass charts of all patients (Figs. 1-4). Bone age was accelerated by a median of two years in patients $1-3$, and in patient 4 it was slightly accelerated (by half a year).

\section{Results of diagnostic process}

Hypercortisolaemia was confirmed by a high level of UFC in three daily urine collections in all patients as well as by an abnormal daily rhythm of cortisol secretion with lack of nocturnal decline at midnight (Table II). All patients had elevated or non-suppressed ACTH level. There was no suppression of cortisol secretion in ODST in patients 1-3. In patient 2 an in- hibition of cortisol in the test with a high dose of dexamethasone $(8 \mathrm{mg}$ ) was observed (cortisol $1.2 \mu \mathrm{g} / \mathrm{dl}$ ). The $\mathrm{CRH}$ test performed in patients 2-4 showed an increase of over $35 \%$ in ACTH and in cortisol by more than $20 \%$. Plasma renin and aldosterone activity were normal in all patients. Adrenal androgens (DHEA-S) were elevated only in patient 2 (Table II).

It is worth underling that in the youngest patient (patient 4), studies carried out at the time of her first visit in our outpatient clinic revealed the following: one-time determination of cortisol in the diurnal collection of urine, morning $\mathrm{ACTH}$, cortisol and 17-OHP values were normal. MRI of the hypothalamic-pituitary area performed at the age of eight years showed no deviations. Due to the clearly cyclical course of the disease, it was decided to continue observation of the patient. After half a year, the patient was referred for re-evaluation of the hypothalamic-pituitary-adrenal axis and a repeat MRI of the hypothalamic-pituitary area because of repeated, rapid weight gain accompanied by nocturnal anxieties, exacerbation of depressive behaviour, insomnia, and excessive sweating.

Densitometry examination of the lumbar spine showed a decrease in bone mineralisation in patients 1-3 and no abnormalities in patient 4. Z-score values were as follows: -2.7 (patient 1), from -1.8 to -2.3 (patient 2), and -2.3 (patient 3).

Finally, MRI of the hypothalamic-pituitary region revealed adenoma in all patients; however, in two of them it was not visible in first MRI but was visible in the neuroimaging repeated six months after the previous examination (Table I).

\section{Results of treatment}

All patients underwent total transsphenoidal resection of the pituitary adenoma. Patient 1 and patient 4 were prepared for the neurosurgery with ketoconazole. Histopathological examination confirmed densely granulated pituitary corticotropic adenoma with varied Ki67 expression. Patient 1 had a double pituitary adenoma composed of densely granulated corticotroph and densely granulated somatotroph cells, although in prior neurosurgery she had presented with no clinical features of excess growth hormone and her IGF-1 level was normal (366.5 ng/ml, normal range 214-753 ng/ml).

All patients met the criteria of early remission of CD, but they required supplementation for different times after surgery, for 0.5 - 40 months, median 4.5 months (Table I). Puberty was undergone normally, regular menstruation cycles reappeared, and normalisation of BMD was observed. In spite of the first patient, who lost the final target height due to an L2 vertebra compression fracture, the height velocity improved after surgery. However, all patients still present obesity or overweight (Figs. 1-4). Biochemical diagnostics has confirmed late remission of all patients.

Pituitary MRI examination repeated regularly after surgery has not showed signs of regrowth of the tumour mass in three patients. In the oldest one, there is a suspicion of regrowth of the tumour, although currently neither clinical nor biochemical signs have confirmed this. We plan to repeat the diagnostic process. 


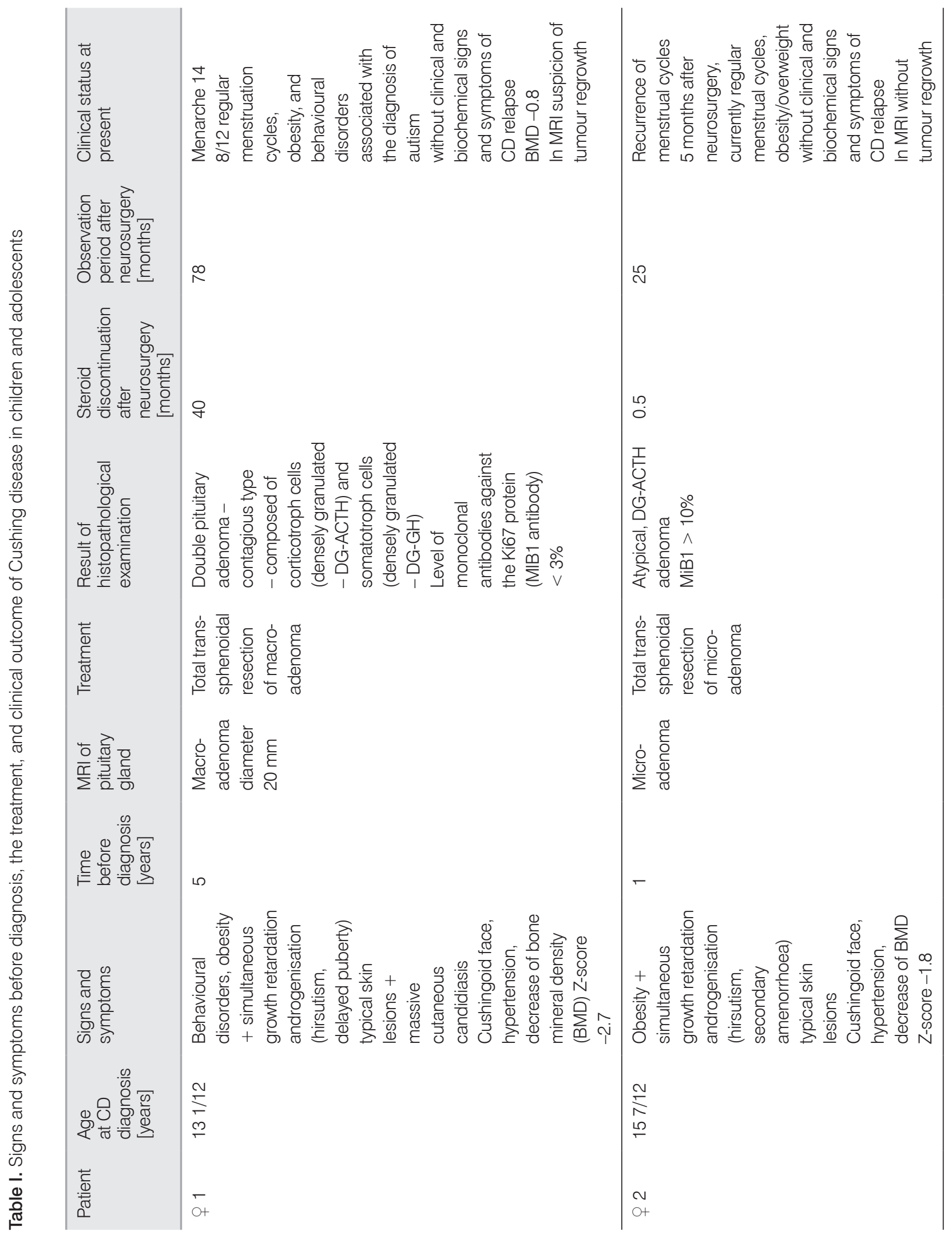




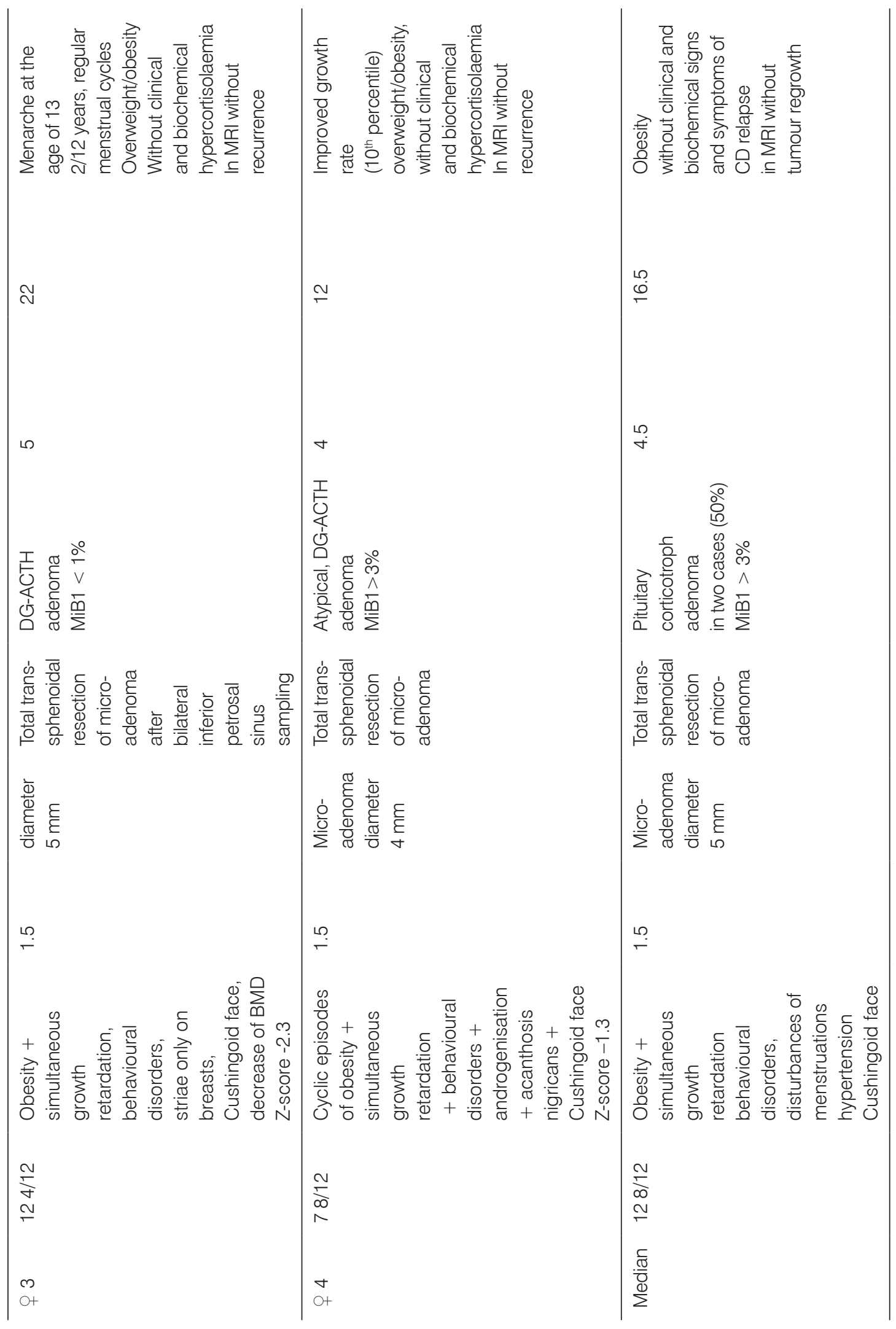


A

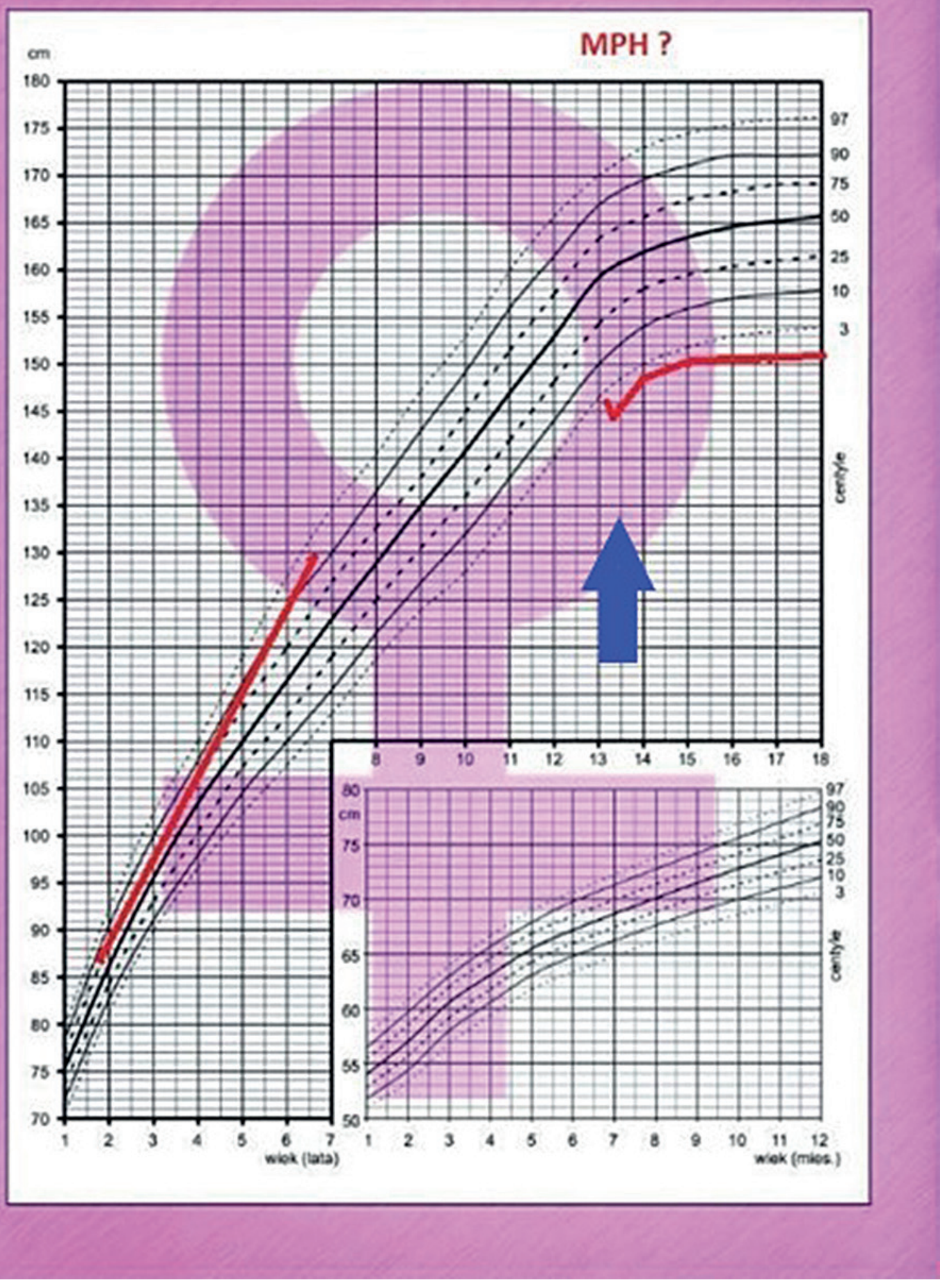

Figure 1. Growth chart (A) and body mass chart (B) of patient 1. Blue arrow indicates the time of neurosurgery 
B

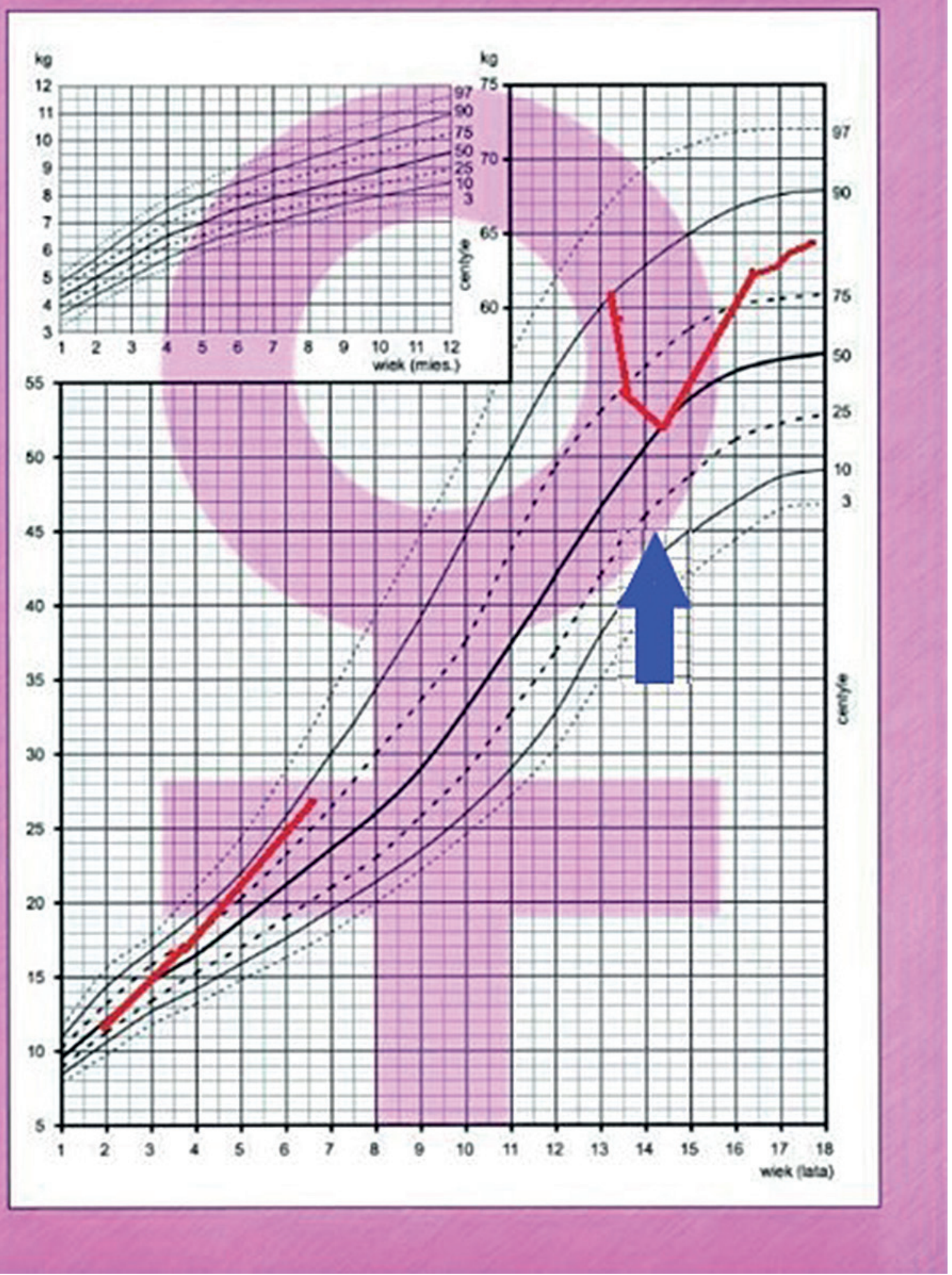

Figure 1. Growth chart (A) and body mass chart (B) of patient 1. Blue arrow indicates the time of neurosurgery 
A

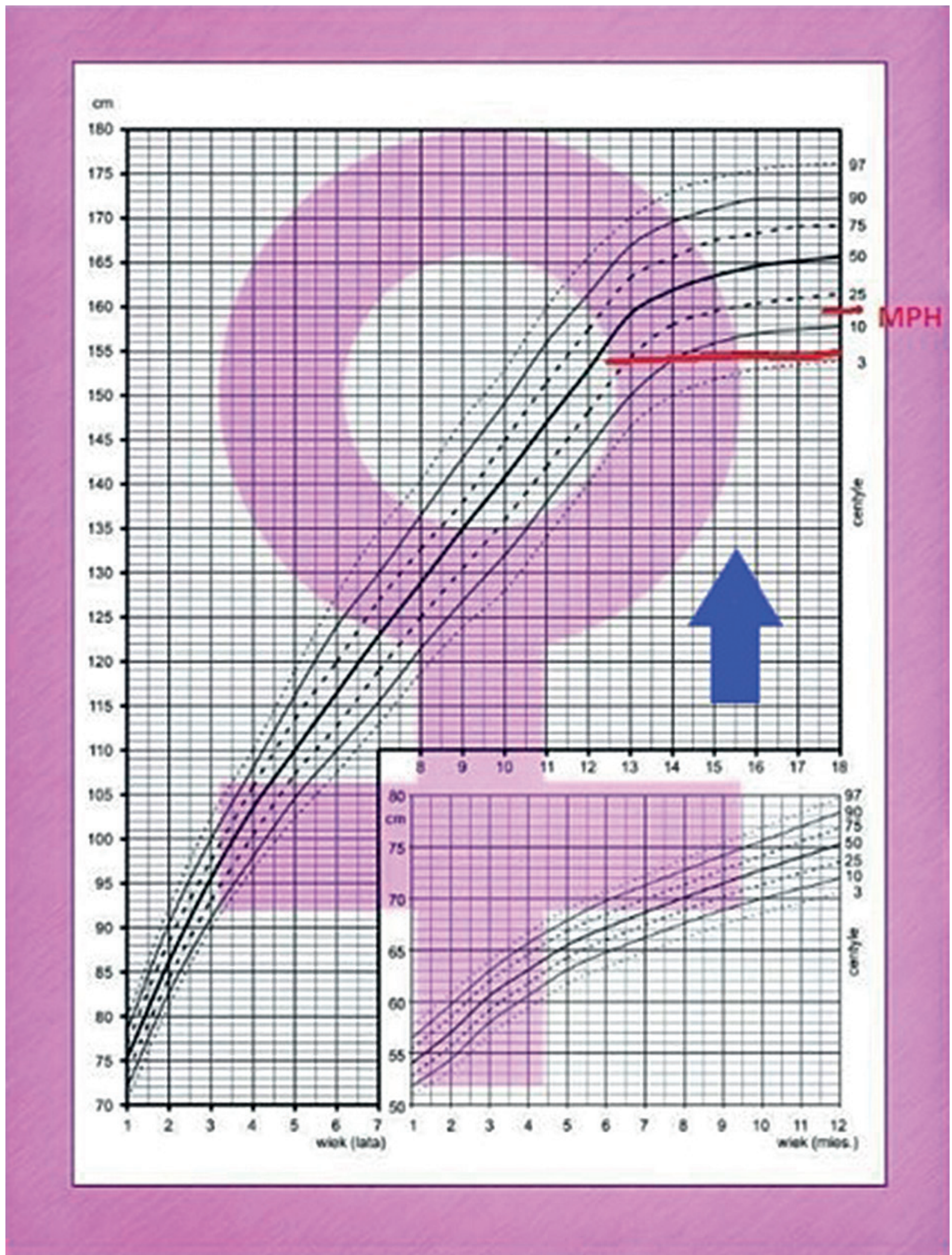

Figure 2. Growth chart (A) and body mass chart (B) of patient 2. Blue arrow indicates the time of neurosurgery 
B

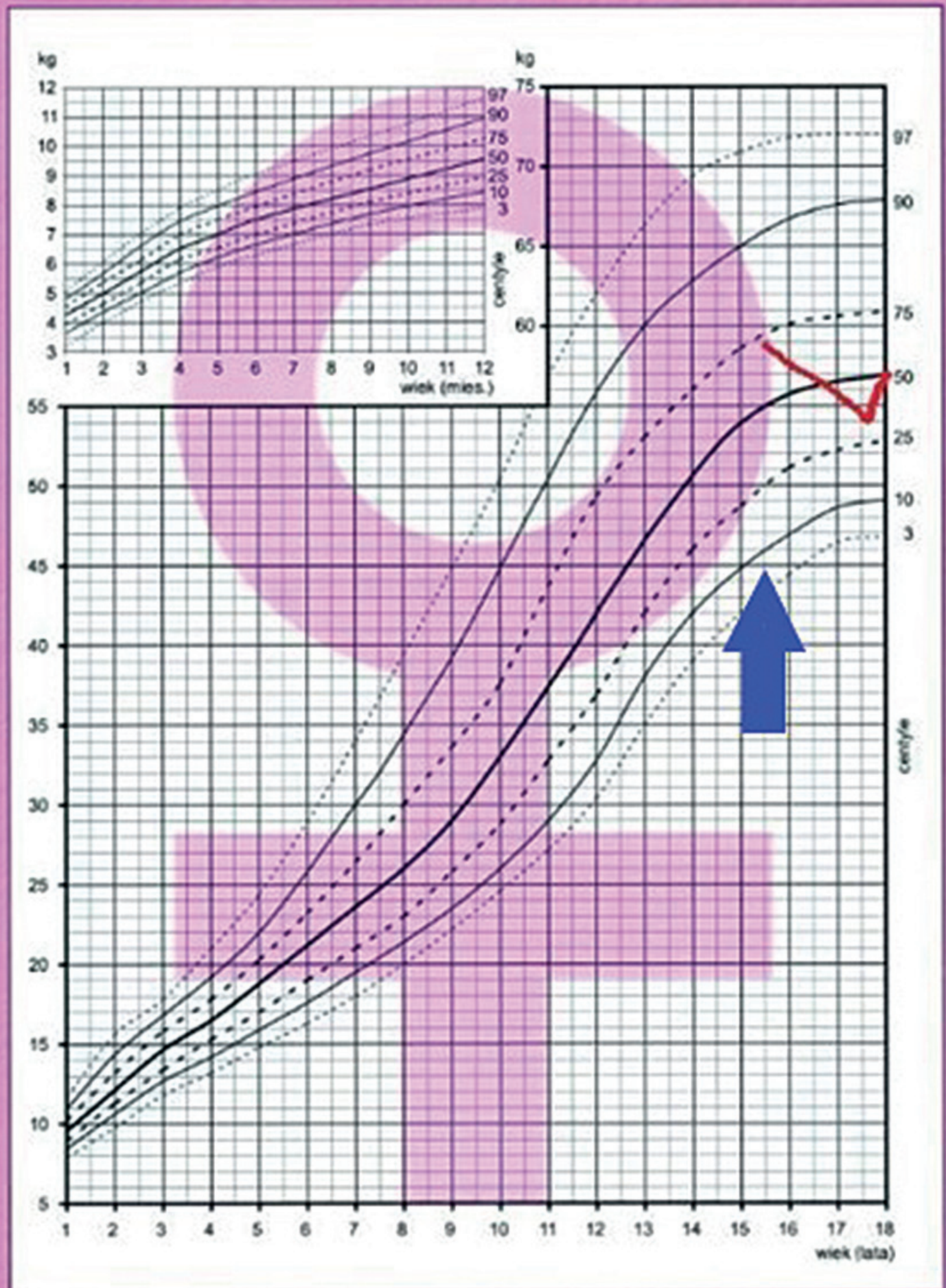

Figure 2. Growth chart (A) and body mass chart (B) of patient 2. Blue arrow indicates the time of neurosurgery 
A

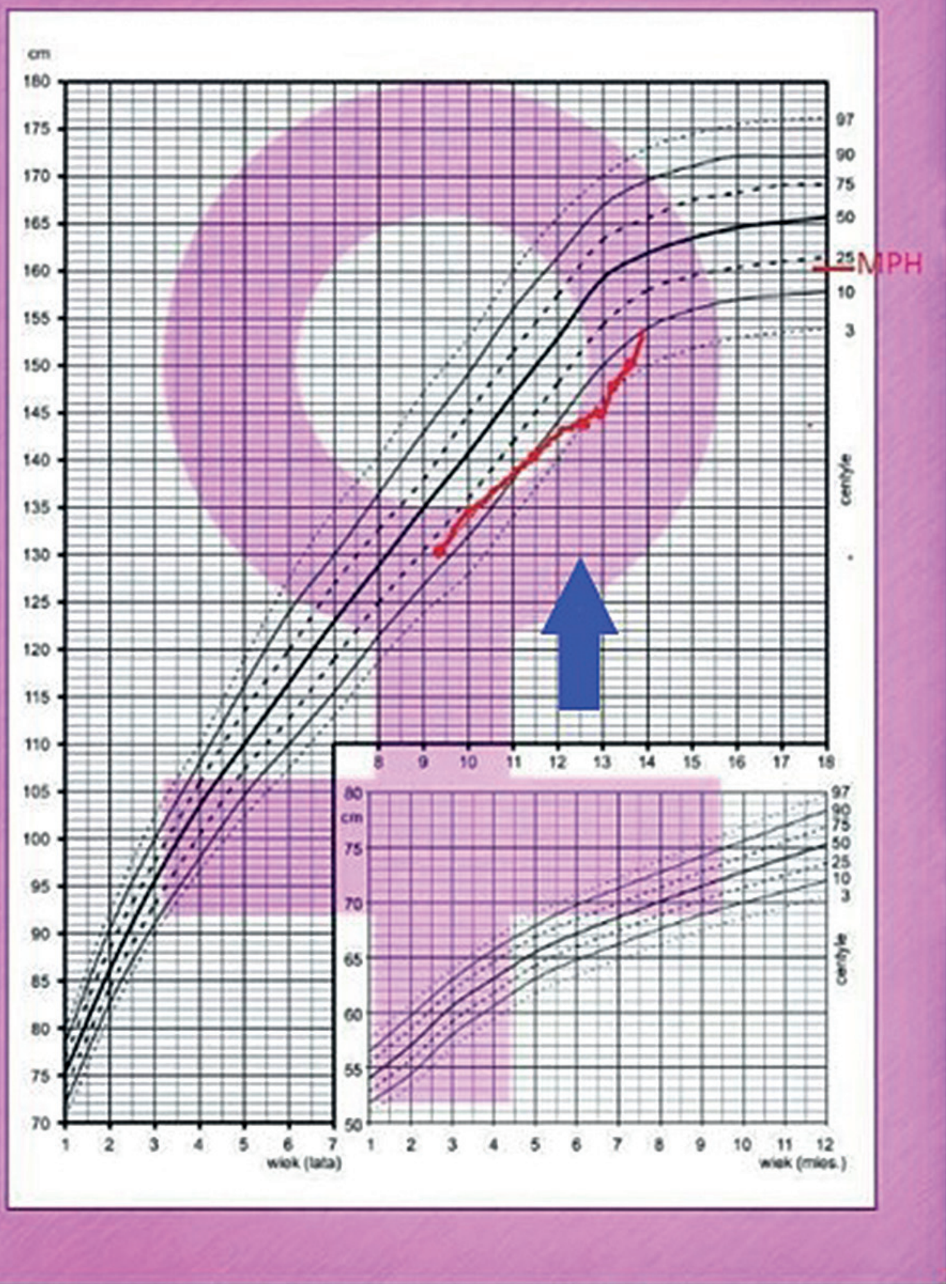

Figure 3. Growth chart (A) and body mass chart (B) of patient 3. Blue arrow indicates the time of neurosurgery 
B

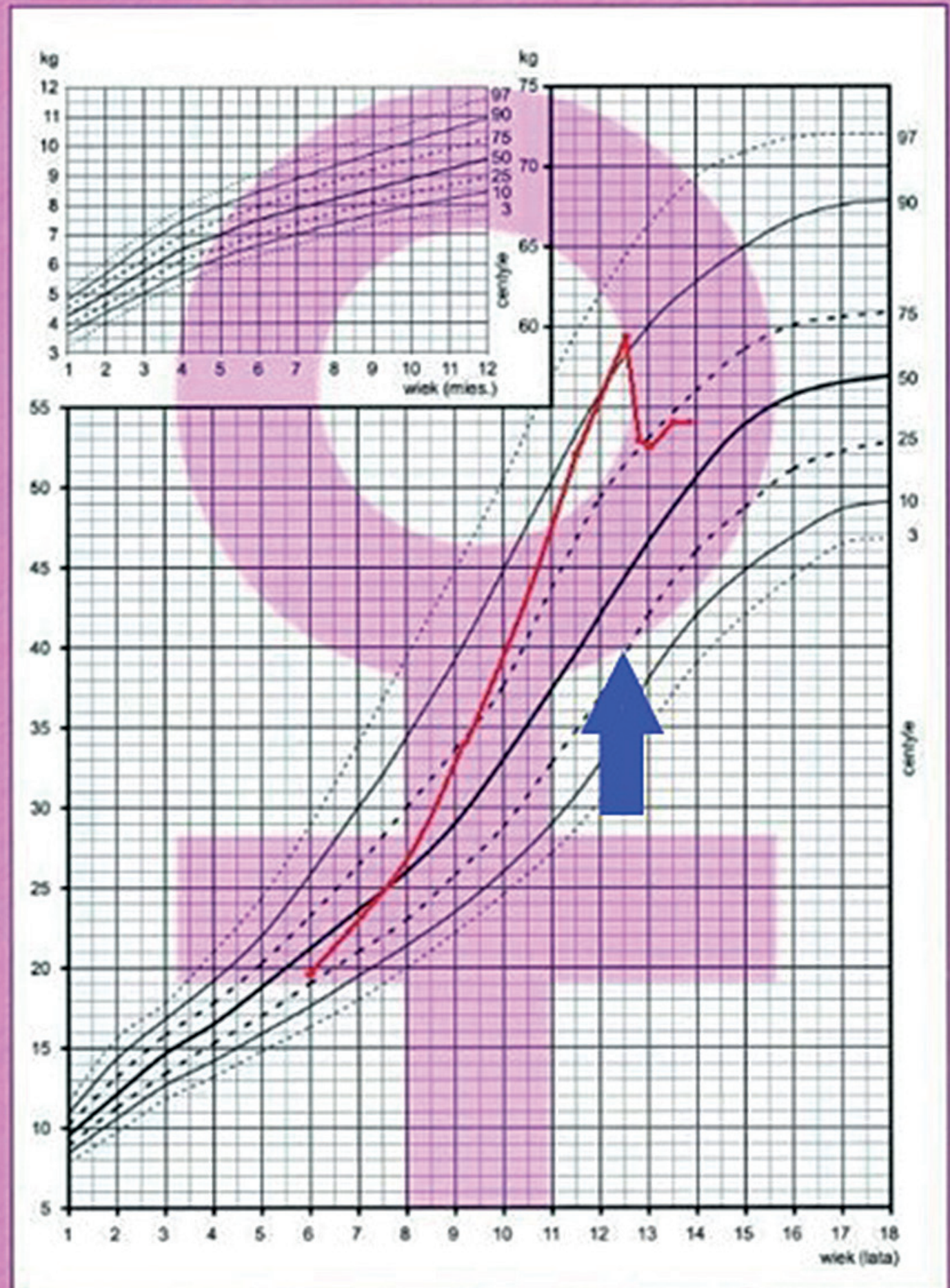

Figure 3. Growth chart (A) and body mass chart (B) of patient 3. Blue arrow indicates the time of neurosurgery 
A

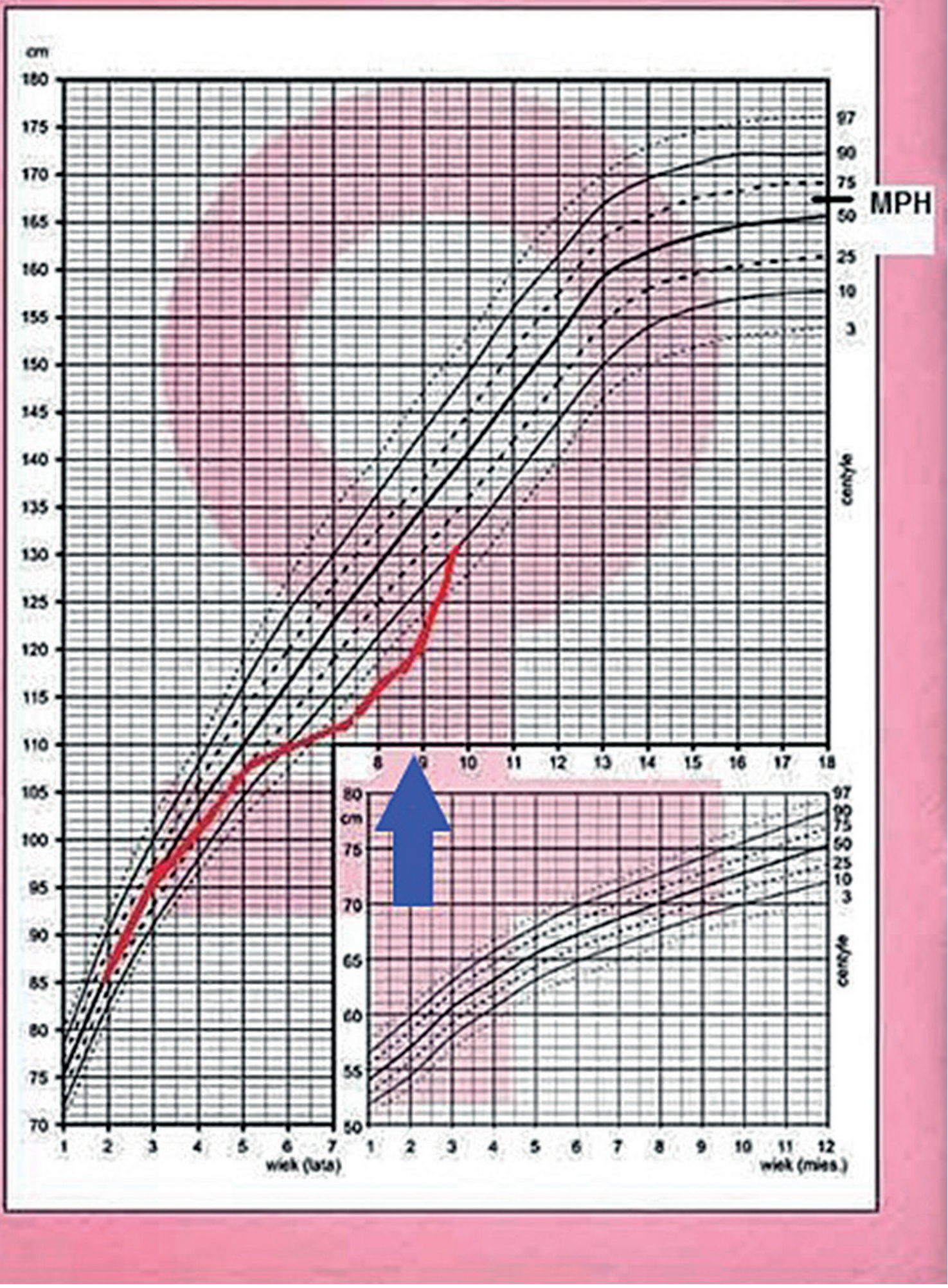

Figure 4. Growth chart (A) and body mass chart (B) of patient 4. Blue arrow indicates the time of neurosurgery 
B

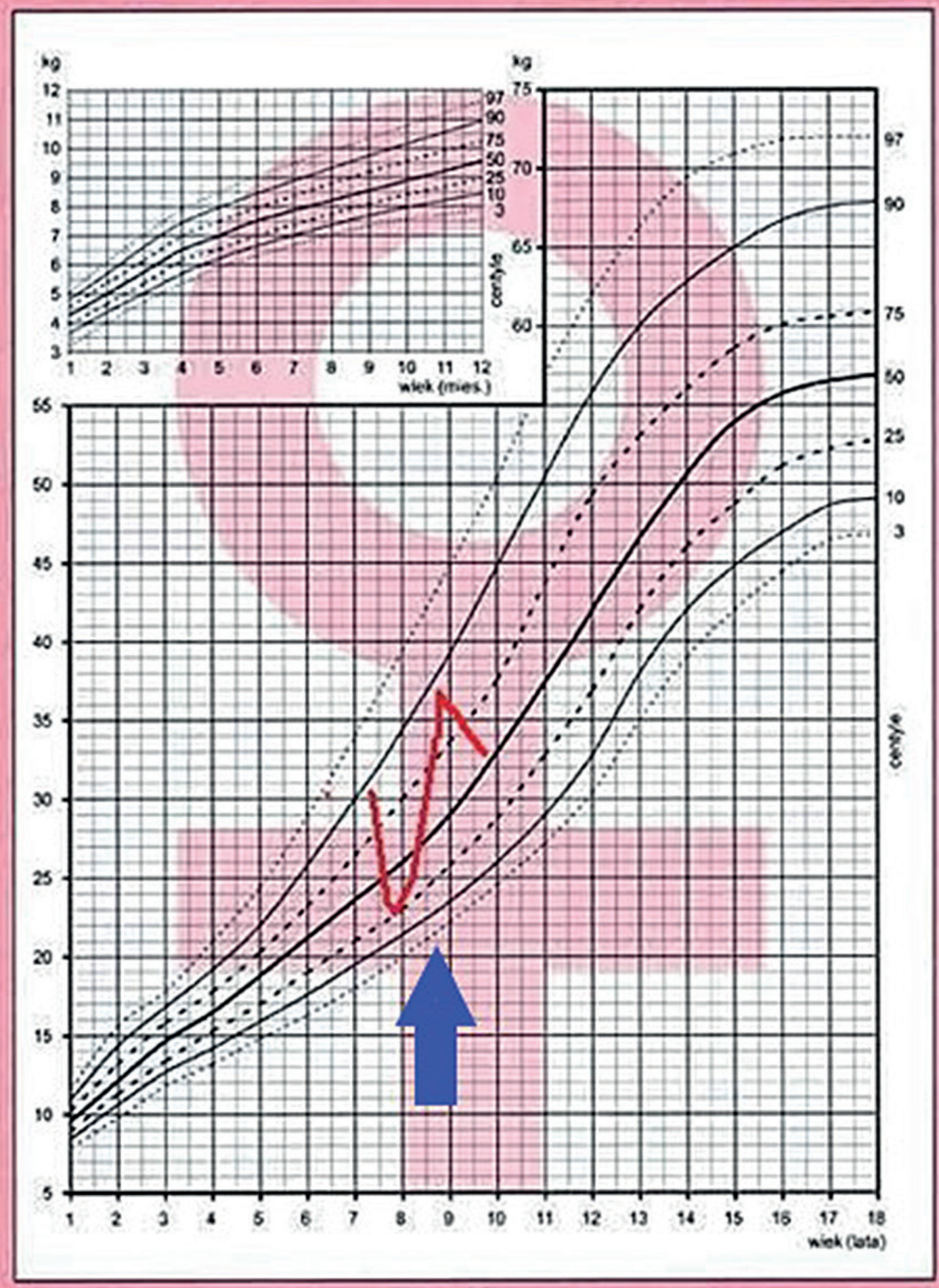

Figure 4. Growth chart (A) and body mass chart (B) of patient 4. Blue arrow indicates the time of neurosurgery 
Table II. Details of biochemical diagnostics of patients with Cushing disease

\begin{tabular}{|c|c|c|c|c|c|}
\hline Patient & $\begin{array}{l}\text { Results of } 24-h \text { urine } \\
\text { collection for cortisol } \\
{[\mu \mathrm{g} / \text { day }]}\end{array}$ & $\begin{array}{l}\text { Diurnal rhythm } \\
\text { of cortisol }[\mu \mathrm{g} / \mathrm{dl}]\end{array}$ & $\begin{array}{l}\text { Results of ODST } \\
{[\mu \mathrm{g} / \mathrm{dl}]}\end{array}$ & Results of $\mathrm{CRH}$ test & $\begin{array}{l}\text { Levels of ACTH } \\
{[\mathrm{pg} / \mathrm{ml}]}\end{array}$ \\
\hline No 1 & $\begin{array}{l}\text { 1) } 164.8 \\
\text { 2) } 560.2 \\
\text { 3) } 273.5\end{array}$ & $\begin{array}{l}8 \text { a.m. }-20.08 \\
4 \text { p.m. }-14.53 \\
8 \text { p.m. }-16.93 \\
\text { midnight }-22.4\end{array}$ & 10.8 & Undone & 156.9 \\
\hline No 2 & $\begin{array}{l}\text { 1) } 557.02 \\
\text { 2) } 602.82 \\
\text { 3) } 292\end{array}$ & $\begin{array}{l}8 \text { a.m. }-18.7 \\
4 \text { p.m. }-8.83 \\
8 \text { p.m. }-8.8 \\
11 \text { p.m. }-14.6\end{array}$ & 2.16 & $\begin{array}{l}\text { Increase of } 62 \% \\
\text { in ACTH and } 22 \% \\
\text { in cortisol }\end{array}$ & 70.4 \\
\hline No 3 & $\begin{array}{l}\text { 1) } 119.9 \\
\text { 2) } 124.9 \\
\text { 3) } 430\end{array}$ & $\begin{array}{l}8 \text { a.m. }-15.52 \\
8 \text { p.m. }-13.32 \\
11 \text { p.m. }-16.5\end{array}$ & 12.28 & $\begin{array}{l}\text { Increase of } 126 \% \\
\text { in ACTH and } 157 \% \\
\text { in cortisol }\end{array}$ & 109.7 \\
\hline No 4 & $\begin{array}{l}\text { 1) } 219 \\
\text { 2) } 284 \\
\text { 3) } 283\end{array}$ & $\begin{array}{l}8 \text { a.m. }-9.5 \\
8 \text { p.m. }-18.5 \\
\text { midnight }-25.4\end{array}$ & 1.02 & $\begin{array}{l}\text { Increase of } 46 \% \\
\text { in ACTH and } 45 \% \\
\text { in cortisol }\end{array}$ & 37.9 \\
\hline
\end{tabular}

Normal ranges: 24-h urine collection for cortisol: children 2-27, adolescents 5-55 $\mu \mathrm{g} /$ day; ACTH: 10-60 pg/ml; cortisol at 8.00 a.m. - 5-23 $\mu \mathrm{g} / \mathrm{dl}$, midnight $<4.4 \mu \mathrm{g} / \mathrm{d}$; ODST cortisol $<1.8 \mu \mathrm{g} / \mathrm{dl}$; positive result of $\mathrm{CRH}$ test: increase of over $35 \%$ in ACTH and in cortisol of over $20 \%$

\section{Discussion}

Cushing disease in children older than seven years accounts for about $75 \%$ of cases. The peak incidence of CD in paediatric patients is during adolescence, with a median age according to various studies ranging from 12.3 to 14.1 years $[4,5]$. CD occurs very rarely and, as in adults, there is a predominance of females over males. The median age in our presented group was 12.3 years, and they were only girls. No explanation for the differences in the incidence and clinical history of CD between the sexes was found [6]. In the majority of the paediatric population with $C D$, germinal mutations that could be the cause of ACTH pituitary tumour production have not been identified; however, MEN1 syndrome cannot be excluded, because CD may be the first manifestation of this condition in children [7]. In addition, some patients have been identified with a somatic mutation in the USP8 deubiquitinase gene in ACTH pituitary tumour cells that may be involved in the molecular pathogenesis of the disease [8].

In children with $C D$, rapid weight gain accompanied by inhibition of growth velocity is an early, sensitive, and most characteristic symptom [2]. In the present work, rapid weight gain and inhibition of growth velocity in all patients were observed. This is clearly illustrated by the presentation of patient 4 with cyclic $\mathrm{CD}$, in whom during hypercortisolaemic periods the growth ve- locity inhibition was accompanied by subsequent weight gain, and during the remission periods the patient lost weight and her growth curve ran linearly parallel to normal growth curves on the growth chart (Fig. 4). Other symptoms of CD in children are (as in adults): truncal obesity, moon face with plethora, buffalo hump, hirsutism, arterial hypertension, and behavioural and mental disorders. Skin lesions are also characteristic: purple striae, acne, hirsutism, hyperpigmentation of the skin, acanthosis nigricans, fungal infections, and easy bruising. All of our patients had bruising, acne, and hirsutism, while striae, hyperpigmentation, and acne occurred in three of them. Striae, which are skin lesions most commonly associated with CS, were not visible in the youngest of the patients. In our youngest patient features of premature puberty were also found, as described in prepubertal CD patients [4, 9]. Acceleration of bone age was observed in all our patients, and it was markedly associated with the intensification of hyperandrogenaemia. Patients 1 and 2 also had hypertension. In all patients, changes in behaviour and changes in facial features were observed. According to the latest meta-analysis of symptoms in children with CD changes in facial features, which are found in all patients, followed by rapid weight gain and virilisation symptoms, hirsutism, emotional lability, fatigue, and headache are dominating. Growth inhibition was found only in $37 \%$ of cases, but in more than $95 \%$ of cases a significant difference between 
SDS growth (which was below 0) and SDS BMI was observed, which was +1.5 SD [4]. The cyclical form of the disease, manifested by regression of clinical symptoms with normalisation of hormonal tests, is observed in $5-15 \%$ of patients $[3,4,10,11]$. Due to the heterogeneity of symptoms of CD described above, sometimes many months pass from their occurrence to diagnosis. In our work the median of this time was 1.5 years. According to the literature, this time can range from three months to seven years, on average 3 years [12]

Diagnosis of CS was based on typical clinical features and a confirmation of hypercortisolaemia in biochemical tests. The first stage of biochemical diagnostics is the confirmation of hypercortisolaemia using a screening test, which is the three-fold 24-h collection of UFC. The sensitivity of a single test is $70 \%$, and in the case of the repeated one it reaches $88 \%$. Complementary testing may also be the determination of urinary 17-hydroxysterides (17 OHS) in 24-h urine collections [13]. Elevated UFC exceeding the reference values for the patient's age are the confirmation of hypercortisolaemia although false positive results may occur in cases of chronic emotional and physical stress, long-lasting, chronic obesity, depression, poorly balanced diabetes, intense physical exercise, depression, alcoholism, anorexia, malnutrition, drug withdrawal, psychogenic polydipsia, and pregnancy. These states are referred to as pseudo-Cushing [3]. Moreover, in girls during adolescence a physiological increase in the excretion of free cortisol in the urine occurs [14].

In children, a very sensitive indicator of hypercortisolaemia is the lack of typical diurnal variability of serum cortisolaemia, especially nocturnal decline, and in particular the typical suppression of cortisol secretion at midnight [3, 13], which was visible in all patients. It is considered that cortisol levels higher than $4.4 \mu \mathrm{g} / \mathrm{dl}$ clearly confirm the diagnosis of CD in children. This test has $99 \%$ sensitivity and 100\% specificity. This value differs between children and adults, in whom it is $7.5 \mu \mathrm{g} / \mathrm{dl}$ [15]. Single ACTH and cortisol values are not diagnostically useful due to their high variability caused not only by the daily rhythm of production of these hormones, but also by the modulating effect of endo- and exogenous factors. In the paediatric population, the assessment of the cortisol concentration in the patient's saliva during the night could be useful with high sensitivity (95.2\%) and specificity (100\%) for hypercortisolaemia [12]. Another standard test in the diagnosis of hypercortisolaemia is an overnight dexamethasone suppression test (ODST) (1 mg, in children $15 \mu \mathrm{g} / \mathrm{kg}$, maximum $1 \mathrm{mg})[12,16,17]$. This test has a $15-20 \%$ risk of false positive results, especially in very obese people. In the night test with $1 \mathrm{mg}$ dexamethasone, there was no inhibition of cortisol in three patients (cases 1, 2, and 3), and one patient showed inhibition of cortisol (case 4). These clinical data confirm that the suppression test results of dexamethasone in children with Cushing syndrome should be interpreted with caution.

Therefore, a recognised standard in paediatrics is to perform a low-dose dexamethasone test administered for 48 hours at a dose of $30 \mu \mathrm{g} / \mathrm{kg} / \mathrm{d}$, maximum $0.5 \mathrm{mg}$ per dose, for the determination of cortisolaemia in fraction 0 , after 24 and after 48 hours. This test has a sensitivity of more than $90 \%$ in the diagnosis of CD [5]. This test can be replaced by a suppression test with a high dose of dexamethasone (in paediatric practice, $120 \mu \mathrm{g} / \mathrm{kg}$ b.w. per dose, maximum $8 \mathrm{mg}$ ), which is given at 11.00 p.m. with the measurement of cortisol levels at 8 a.m. the same and the next day. Suppression of its concentration above the cortisol value from the previous day (above 50\%) is confirmation of CD. This test has a high sensitivity of $88 \%$ but rather a low specificity of $57 \%$, associated with false positive test results in obese people [18].

Diagnostic difficulties in the diagnosis of hypercortisolaemia appear in the case of the cyclic form of CD. If this form of $C D$ is suspected, long-term observation of the patient is recommended, with particular attention paid to the course of the growth process. This CD form must also be differentiated from PPNAD, which runs cyclically, but is ACTH-independent CS with a marked inhibition of ACTH secretion with the paradoxical excessive cortisol response of the dexamethasone test [19]. Another problem in the diagnosis of CD is its differentiation with pseudo-Cushing syndrome. To distinguish these two forms, it is recommended that a combined test be performed, i.e. a dexamethasone suppression test with a $\mathrm{CRH}$ supply. It consists in administering eight doses of dexamethasone $(30 \mu \mathrm{g} / \mathrm{kg} / \mathrm{d}$ maximum $0.5 \mathrm{mg}$ per dose) every 6 hours (the test lasts 48 hours) and then performing the test with $\mathrm{CRH}$ $(1 \mu \mathrm{g} / \mathrm{kg}$, maximum $100 \mu \mathrm{g} \mathrm{IV})$ with assessment of ACTH and cortisol at the following time points: $-15 \mathrm{~min},-5 \mathrm{~min}, 0 \mathrm{~min}$, and +15 min. Patients with pseudo-Cushing syndrome will have uncertain or very low values of both parameters and no response to $\mathrm{CRH}$ stimulation [3]. In patients with $\mathrm{CD}$ higher initial values of cortisol and $\mathrm{ACTH}$ are observed in the $\mathrm{CRH}$ test, as well as a noticeable response of cortisol to $\mathrm{CRH}$. A cortisol concentration higher than $1.4 \mu \mathrm{g} / \mathrm{dl} 15$ min after administration of $\mathrm{CRH}$ speaks for the diagnosis of $\mathrm{CD}$. Another test that differentiates these two disease entities seems to be the measurement of cortisol at midnight. Patients with pseudo-Cushing syndrome have a cortisol level at midnight that is lower than $7.5 \mu \mathrm{g} / \mathrm{dl}$, which differentiates them from CD patients [20]. These data concern adults. Therefore, in children, it seems that, similarly to the diagnosis of hypercortisolaemia, the value of $4.4 \mu \mathrm{g} / \mathrm{dl}$ should be considered as differentiating the case of CD from pseudo-Cushing syndrome. However, this is a hypothesis of the authors of this work and is not confirmed by the results of a clinical trial. The occurrence of pseudo-Cushing syndrome is extremely rare in children, so it is difficult to have a sufficiently large cohort for research.

After documenting hypercortisolaemia, localisation tests should be performed to confirm CD, i.e. ACTH-dependent CS, which include $\mathrm{ACTH}$ concentration measurement, $\mathrm{CRH}$ test, and (in patients with suspected CD) imaging of the pituitary gland. If there is an absence of the visualisation of a focal lesion in the pituitary, bilateral inferior petrosal sinus catheterisation with $\mathrm{ACTH}$ evaluation before and after $\mathrm{CRH}$ stimulation should be performed [21].

Adrenocorticotropic hormone levels above $29 \mathrm{ng} / \mathrm{l}$, which were present in all patients, indicate ACTH-dependent CS 
with high sensitivity (70\%) and specificity (100\%) according to the data from the literature [13]. The next stage of diagnosis is the $\mathrm{CRH}$ test at a dose of $1 \mu \mathrm{g} / \mathrm{kg}$, maximum $100 \mu \mathrm{g}$ IV, characterised by $91 \%$ sensitivity and $100 \%$ specificity. An increase in ACTH levels of over $35 \%$ and cortisol of more than $20 \%$ after administration of $\mathrm{CRH}$ confirms $\mathrm{CD}$.

The presence of a microadenoma in the pituitary MRI examination, usually smaller than $3-4 \mathrm{~mm}$, is found in about half of the cases. In two large studies including paediatric patients, pituitary adenomas were found in 63\% and 55\% [22]. However, in a multicentre analysis of 1284 paediatric patients who underwent neurosurgical treatment due to the pituitary adenoma, patients with CD (i.e. the presence of confirmed ACTH-secreting pituitary adenoma) are the largest group, constituting $43 \%$ of the whole [23]. In all patients, MRI examination showed a pituitary adenoma responsible for the CD; however, in two of them (50\%) the microadenoma was revealed in MRI re-examination. In the standard procedure, in the absence of a pituitary lesion in the MRI examination, it is recommended that a catheterisation of the petrosal sinuses be performed. This procedure assesses ACTH levels from blood samples collected from the sinuses on both sides before and after $\mathrm{CRH}$ stimulation, but also ACTH from peripheral blood, which may help in the diagnosis of ACTH-dependent CS due to the excess of ectopic ACTH, which is very rarely diagnosed in children.

After confirming CD, the patient is qualified for surgery. The treatment of choice is transsphenoidal tumour resection. The effectiveness of the procedure depends primarily on the neurosurgeon's experience. In paediatric centres, the effectiveness of this treatment reached from $62 \%$ to $98 \%$ [24]. Remission of the CD in 200 paediatric patients was achieved in $98 \%$, but only $3 \%$ of them had normal levels of cortisol, and the remaining $97 \%$ presented hypocortisolaemia, which is a typical response to the rapid elimination of excess ACTH, as well as earlier adrenal axis dysregulation. All our patients required transient hydrocortisone substitution, and the time of its supply clearly depended on the duration of the period from the first symptoms of the CD to its diagnosis. The symptoms of hypercortisolaemia usually disappear gradually over several months after surgery. Skin changes present at the time of diagnosis disappear gradually. According to observations of paediatric centres, acne, acanthosis nigricans, hyperpigmentation of the skin, and ease of bruising disappear up to three months after the surgery and hirsutism up to nine months after the surgery. Striae remain, which change their severity and colour from purple to pale-silver [25]. In 30\% of patients successfully cured neurosurgically, disease relapse is observed.

The result of the histopathological examination supplemented with the immunohistochemical method of Ki-67 antigen labelling provides information on the degree of tumour proliferation and may have a significant clinical diagnostic significance for the course of the disease [26-28]. Tumours with invasive growth, elevated MIB-1 proliferation index, and nuclear response to P53 are referred to as "atypical" pituitary adenomas $[26,29]$. Such a diagnosis was made in two of the described patients, who, in the 1.5- and 0.5-year follow-up, have no signs of tumour recurrence. Some reports indicate that adenomas with MIB-1 proliferation index above $3 \%$ are characterised by unfavourable clinical course [27].

In patients in whom the neurosurgical treatment did not give the expected results, radiotherapy is used as the second line of therapy [30].

Despite the successful treatment of $C D$, in children and adolescents remaining in persistent remission of $C D$ there are body composition disorders with visible reduction of bone mass and abdominal obesity [31]. Disorders of bone mineralisation were found in all presented patients. In the long-term observation, gradual normalisation of bone mass is observed, which is best illustrated by the densitometry results of the first of the described patients remaining in the longest observation. In the long-term observation of paediatric patients after CD treatment, an excess of total and visceral adipose tissue is observed $[13,31]$, which may be a risk of development of metabolic syndrome and cardiovascular disorders in the future. Obesity is still observed in all presented patients.

Due to the rare incidence of $C D$ in children, the limitation of our study was the small number of analysed patients, which limits the strength of the conclusion.

\section{Conclusions}

Typical symptoms of CD in children, which are the inhibition of growth velocity with increasing obesity and behavioural disorders, are sometimes not noticed for a long time by their parents/careers and general practitioners. In each case of the coexistence of growth velocity inhibition (not necessarily short stature) with weight gain (not necessarily obesity), the appearance of hyperandrogenism, and depressive-anxiety disorders, the biochemical diagnostics of CS should be performed in accordance with the applicable diagnostic standard for the type of tests, their order, and interpretation of results. To diagnose $\mathrm{CD}$, it is not necessary to visualise the microadenoma in MRI.

The diagnostic difficulty may be caused by the cyclical form of Cushing's disease, in which remission periods are observed with weight loss, normalisation of growth velocity, and normalisation of hormonal test results.

The treatment of choice is transsphenoidal resection of the ACTH-secreting micro/macroadenoma, which, if complete, causes a reduction of the clinical symptoms of the disease.

In most patients after neurosurgery, hydrocortisone substitution is necessary in the period depending on the duration of symptoms before the diagnosis of the disease. Obesity can be a chronic complication of CD, even after effective treatment. All patients should be carefully monitored by an experienced endocrinologist. 


\section{References}

1. Starzyk JB. Zespół Cushinga. In: Kawalec W, Gręda R, Ziółkowska $\mathrm{H}$, et al. (eds.). Pediatria. Wydawnictwo Lekarskie PZWL, Warszawa 2018: 966-976.

2. Savage MO, Chan LF, Afshar F, et al. Advances in the Management of Paediatric Cushing's Disease. Horm Res 2008; 69: 327-333. doi: 10.1159/000117388

3. Stratakis A. Cushing Syndrome in Pediatrics. Endocrinol Metab Clin North Am 2012; 41: 793-803.

4. Storr HL, Savage MO. Management of endocrine disease: Paediatric Cushing's disease. Eur J Endocrinol. 2015; 173: 35-45. doi: 10.1097/MED.0b013e328305082f

5. Storr HL, Chan LF, Grossman AB, Savage MO. Pediatric Cushing's syndrome: epidemiology, investigation and therapeutic advances. Trends Endocrinol Metab 2007; 18: 167-174. doi: 10.1016/ j.tem.2007.03.005

6. Libuit LG, Karageorgiadis AS, Sina N, et al. A gender-dependent analysis of Cushing's disease in childhood: pre- and post-operative follow-up. Clin Endocrinol (Oxf) 2015; 83: 72-77. doi: 10.1111/ cen. 12644 .

7. Cuny T, Pertuit M, Sahnoun-Fathallah M, et al. Genetic analysis in young patients with sporadic pituitary macroadenomas: besides AIP don't forget MEN1 genetic analysis. Eur J Endocrinol 2013; 168: 533-541. doi: 10.1530/EJE-12-0763

8. Reincke M, Sbiera S, Hayakawa A, et al. Mutations in the deubiquitinase gene USP8 cause Cushing's disease. Nature Genet 2015; 47: 31-38. doi: 10.1038/ng.3166.

9. Magiakou MA, Chrousos GP. Cushing's syndrome in children and adolescents: current diagnostic and therapeutic strategies. J Endocrinol Invest. 2002; 25: 181-194.

10. Brown RD, Van Loon GR, Orth DN, Liddle GW. Cushing's Disease with Periodic Hormonogenesis: One Explanation for Paradoxical Response to Dexamethasone. J Clin Endocrinol Metab 1973; 36 : 445-451. doi: 10.1210/jcem-36-3-445

11. Alexandraki KI, Kaltsas GA, Isidori AM, et al. The prevalence and characteristic features of cyclicity and variability in Cushing's disease. Eur J Endocrinol 2009; 160: 1011-1018. doi: 10.1530/EJE-09-0046

12. Magiakou MA, Mastorakos G, Oldfield EH, et al. Cushing's syndrome in children and adolescents. Presentation, diagnosis and therapy. N Engl J Med 1994; 331: 629-636. doi: 10.1056/NEJM 199409083311002

13. Batista DL, Riar J, Keil M, Stratakis CA. Diagnostic tests for children who are referred for the investigation of Cushing syndrome. Pediatrics 2007; 120: 575-586. doi: 10.1542/peds.2006-2402

14. Legro RS, Hung Mo Lin, Demers LM, Lloyd T. Urinary Free Cortisol Increases in Adolescent Caucasian Females during Perimenarche. J Clin Endocrinol Metab 2003; 88: 215-219. doi: 10.1210/jc.2002020256

15. Newell-Price J, Trainer P, Perry L, et al. A single sleeping midnight cortisol has $100 \%$ sensitivity for the diagnosis of Cushing's syndrome. Clin Endocrinol (Oxf) 1995; 43: 545-550.

16. Guignat L, Bertherat J. The diagnosis of Cushing's syndrome: an Endocrine Society Clinical Practice Guideline: commentary from a European perspective. Eur J Endocrinol 2010; 163: 9-13. doi: 10. 1530/EJE-09-0627
17. Savage MO, Storr HL, Chan LF, Grossman AB. Diagnosis and treatment of pediatric Cushing's disease. Pituitary 2007; 10: 365-371. doi: 10.1007/s11102-007-0056-4

18. Dichek HL, Nieman LK, Oldfield EH, et al. A comparison of the standard high dose dexamethasone suppression test and the overnight 8-mg dexamethasone suppression test for the differential diagnosis of adrenocorticotropin-dependent Cushing's syndrome. J Clin Endocrinol Metab 1994; 78: 418-422. doi: 10.1210/jcem.78.2.8106630

19. Stratakis CA, Sarlis N, Kirschner LS, et al. Paradoxical response to dexamethasone in the diagnosis of primary pigmented nodular adrenocortical disease. Ann Intern Med 1999; 131: 585-591. doi: 10. 7326/0003-4819-131-8-199910190-00006

20. Papanicolaou DA, Yanovski JA, Cutler GB, et al. A single midnight serum cortisol measurement distinguishes Cushing's syndrome from pseudo-Cushing states. J Clin Endocrinol Metab 1998; 83: 1163-1167. doi: 10.1210/jcem.83.4.4733

21. Zampetti B, Grossrubatscher E, Dalino Ciaramella P, et al. Bilateral inferior petrosal sinus sampling. Endocr Connect 2016; 5: 12-25. doi: 10.1530/EC-16-0029

22. Savage MO, Storr HL. Pediatric Cushing's disease: management issues. Indian J Endocrinol Metab 2012; 16 (Suppl 2): 171-175. doi: 10.4103/2230-8210.104032.

23. Perry A, Graffeo CS, Marcellino C, et al. Pediatric pituitary adenoma: case series, review of the literature, and a skull base treatment paradigm. J Neurol Surg B Skull Base 2018; 79: 91-114. doi: 10.1055/s-0038-1625984

24. Lonser RR, Wind JJ, Nieman LK, et al. Outcome of surgical treatment of 200 children with Cushing's disease. J Clin Endocrinol Metab 2013; 98: 892-901. doi: 10.1210/jc.2012-3604

25. Stratakis CA, Mastorakos G, Mitsiades NS, et al. Skin manifestations of Cushing disease in children and adolescents before and after the resolution of hypercortisolemia. Pediatr Dermatol 1998; 15: 253-258.

26. Hentschel SJ, McCutcheon IE, Moore W, Durity FA. P53 and MIB-1 Immunohistochemistry as predictors of the clinical behavior of nonfunctioning pituitary adenomas. Can J Neurol Sci 2003; 30: 215-219.

27. Kleinschmidt-DeMasters BK. Subtyping does matter in pituitary adenomas. Acta Neuropathol 2006; 111: 84-85. doi: 10.1007/ s00401-005-1105-6

28. Mete O, Ezzat S, Asa SL. Biomarkers of aggressive pituitary adenomas. J Mol Endocrinol 2012; 49: 69-78. doi: 10.1530/JME-12-0113

29. Rijn SJ, Grinwis GCM, Penning LC, Meij BP. Expression of Ki-67, PCNA, and p27kip1 in canine pituitary corticotroph adenomas. Domest Anim Endocrinol 2010; 38: 244-252. doi: 10.1016/j. domaniend.2009.11.003

30. Acharya SV, Gopal RA, Goerge J, et al. Radiotherapy in paediatric Cushing's disease: efficacy and long term follow up of pituitary function. Pituitary 2010; 13: 293-297. doi: 10.1007/s11102-010-0231-x

31. Leong GM, Abad V, Charmandari E, et al. Effects of child- and adolescent-onset endogenous Cushing syndrome on bone mass, body composition, and growth: A 7-year prospective study into young adulthood. J Bone Miner Res 2007; 22: 110-118. doi: 10.1359/ jbmr.061010 